https://helda.helsinki.fi

\title{
Symbiotic cyanobacteria in lichens
}

\section{Rikkinen, Jouko}

World Scientific Publishing Europe

2017-02

Rikkinen , J 2017 , Symbiotic cyanobacteria in lichens . in M Grube , J Seckelbach \& L

Muggia (eds) , Algae and cyanobacteria in symbiosis. World Scientific Publishing Europe,

London , pp. 147-167 . https://doi.org/10.1142/9781786340580_0005

http://hdl.handle.net/10138/309870

https://doi.org/10.1142/9781786340580_0005

unspecified

acceptedVersion

Downloaded from Helda, University of Helsinki institutional repository.

This is an electronic reprint of the original article.

This reprint may differ from the original in pagination and typographic detail.

Please cite the original version. 


\title{
Symbiotic Cyanobacteria in Lichens
}

Jouko Rikkinen

Faculty of Biological and Environmental Sciences, Department of Biosciences, University of Helsinki, Viikinkaari 1, 65 Helsinki, Finland

\begin{abstract}
Cyanolichens are obligate symbioses between fungi and cyanobacteria. They occur in many types of environments ranging from Arctic tundra and semi-deserts to tropical rainforests. Possibly even a majority of their global species diversity has not yet been described. Symbiotic cyanobacteria provide both photosynthate and fixed nitrogen to the fungal host and the relative importance of these functions differs in different cyanolichens. The cyanobiont can either be the sole photosynthetic partner or a secondary symbiont in addition to a primary green algal photobiont. In addition, the cyanolichen thallus may incorporate a plethora of other microorganisms. The fungal symbionts in cyanolichens are almost exclusively ascomycetes. Nostoc is by far the most commonly encountered cyanobacterial genus. While the cyanobacterial symbionts are presently not readily identifiable to species, molecular methods work well on the generic level and offer practical means for identifying symbiotic cyanobacterial genotypes. The present diversity of lichen cyanobionts may partly reflect the evolutionary effects of their lichen-symbiotic way of life and dispersal.
\end{abstract}




\section{Introduction}

Cyanobacteria are ancient monophyletic lineage of unicellular and multicellular prokaryotes that possess chlorophyll $a$ and are capable of oxygenic photosynthesis. Prokaryotic fossils morphologically resembling modern cyanobacteria have been found from Archean deposits and it is generally believed that cyanobacterial photosynthesis raised oxygen levels in the atmosphere around 2.5-2.3 billion years ago, hence establishing the basis for the evolution of aerobic respiration. Recent findings suggest that the non-photosynthetic ancestors of cyanobacteria were anaerobic, motile and obligately fermentative (Di Rienzi et al., 2014).

The first appearance of multicellular cyanobacteria may have coincided with the beginning of the rise of atmospheric oxygen and three clades, representing the majority of extant cyanobacteria, which seem to have evolved soon after (Schirrmeister et al., 2011, 2012). Later, through endosymbiosis, some cyanobacteria evolved into the plastids of photoautotrophic eukaryotes about 900 million years ago (Deusch, 2008; Shih and Matzke, 2013), and the nitrogen fixation of diazotrophic cyanobacteria continues to play a crucial role in the nutrient cycles of many aquatic and terrestrial ecosystems (Zehr, 2011; Elbert et al., 2012; Rousk et al., 2013).

Thousands of species of lichen-forming fungi have cyanobacteria as photosynthetic symbionts and are therefore collectively referred to as "cyanolichens" (Rikkinen, 2002). Many of these, quite possibly even the majority, have not yet been described (e.g., Lumbsch et al., 2011; Lücking et al., 2014; Moncada et al., 2014a, 2014b). Symbioses with cyanobacteria have been established repeatedly in different lineages of Fungi, and convergent evolution has often resulted in similar symbiotic morphologies in distantly related lineages (Muggia et al., 2011). The morphological and physiological characteristics of lichen symbioses tend to be highly specialized, and involve extensive molecular crosstalk between the symbionts (Chua et al., 2012; Junttila et al., 2013; Kampa et al., 2013; Wang et al., 2014).

Within a cyanolichen thallus, the cyanobacterial symbiont or "cyanobiont" provides sugar (glucose) and/or fixed atmospheric nitrogen (as ammonium) to the fungal host or "mycobiont". The mycobiont provides its symbiotic partners water, carbon dioxide, and a relatively stable environment that is relatively well protected from environmental extremes and predation (e.g., Rikkinen, 1995, 2002). 


\section{Morphology and Functional Organization}

On the basis of thallus structure, lichens have traditionally been divided into foliose, fruticose, and crustose species. This division is obviously artificial and convergent forms have evolved in many lichen lineages. Most cyanolichens are foliose, i.e., their growth is predominately horizontal, and the thallus is typically dorsiventral, flat, and lobate (Fig. 1a). Fruticose cyanolichens have upright, shrubby thalli with cylindrical lobes that are often attached to the substrate by a relatively narrow base (Fig. 1b). Crustose cyanolichens have relatively undifferentiated thalli and often grow tightly attached to the substrate (Fig. 1c).

Based on symbiont composition, cyanolichens can be divided into two artificial groups: bipartite and tripartite cyanolichens (Fig. 2a). In most bipartite lichens, the cyanobiont forms a more or less continuous layer immediately below the upper cortex of the thallus (Fig. 2b). The thalli of tripartite cyanolichens, on the other hand, house both green algal and cyanobacterial photobionts (Fig. 2c). In these symbioses, the cyanobacteria tend to represent a small proportion of total photobiont biomass and are usually restricted to special structures called cephalodia (Figs. 1b and 3a-3d). However, there are also some tripartite lichens in which the fungus has two "primary" photosynthetic photobionts both contributing substantially to the photosynthesis of the same thallus (e.g., Henskens et al., 2012). In addition, some green algal lichens establish ephemeral associations with neigh-boring cyanobacteria or cyanolichens, presumably in order to access a supply of fixed nitrogen (Poelt and Mayhofer, 1988; Rambold and Triebel, 1992). The mycobionts of some tripartite lichens can produce different thallus morphologies in symbiosis with compatible green algae and cyanobacteria, respectively. Chimeroid lichens with green algae and cyanobacteria as primary photobionts in different parts of the same thallus are called photosymbiodemes. The two differ-ent morphotypes may either combine into a compound thallus or live separate lives (James and Henssen, 1976; Brodo and Richardson, 1979; Tønsberg and Holtan-Hartwig, 1983; Goffinet and Bayer, 1997; Heiðmarsson et al., 1997; Paulsrud et al., 1998; Stenroos et al., 2003; Aptroot and Schumm, 2009; Magain et al., 2012; Moncada et al., 2013; Magain and Sérusiaux, 2014).

Lichen-symbiotic cyanobacteria can deliver both photosynthate and/or fixed nitrogen to their fungal partners. The relative importance of these two activities varies between bi- and tripartite lichens. The cyanobionts of bipartite lichens tend to show lower heterocyst frequencies and lower rates of nitrogen fixation than those of tripartite species. In tripartite cyanolichens, the cyanobionts 
typically exhibit relatively high rates of nitrogen fixation, while the green algal photobiont typically delivers most of the photosynthate (e.g., Nash, 2008).

While lichens have traditionally been perceived as pairwise interactions between one fungal host and one or two photosynthetic symbionts, many of them actually involve several photobiont species and can also incorporate a plethora of other microorganisms. Recent studies have shown that lichens host diverse and specialized communities of non-phototrophic bacteria, which are likely to play important roles in the symbiosis (Grube et al., 2009; Hodkinson and Lutzoni, 2009; Bates et al., 2011; Hodkinson et al., 2012; Sigurbjörnsdóttir et al., 2014). Also the diversity of obligately lichenicolous fungi is remarkable, both on lichen surfaces and hidden within the inner layers of the thalli (Lawrey and Diederich, 2011; U'Ren et al., 2012; Werth et al., 2013).

Most cyanolichen symbioses are obligate in the sense that the fungal hosts cannot survive without their photosynthetic partners and the cyanobionts do not seem to commonly establish independent free-living populations outside lichen thalli. In many cases, the cyanobionts are vertically transmitted within specialized vegetative propagules and maintained through host generations, insuring a close and long-term symbiosis (e.g., Rikkinen, 2003).

\section{Symbiont Diversity}

Cyanobacteria occur abundantly in aquatic environments and almost in all types of terrestrial ecosystems. A small minority of them form symbiotic associations with eukaryotic organisms such as lichen-symbiotic fungi. Among the Fungi, cyanobacteria form symbioses almost exclusively with ascomycetes (Ascomycota), especially with Lecanoromycetes (Miadlikowska et al., 2014) and Lichinomycetes (Schultz et al., 2001). Comparable symbioses with other types of fungi are rare, with the prominent exceptions of Dictyonema (Fig. 4d) and related basidiomycetes (Dal-Forno et al., 2013; Lücking et al., 2014) and the glomeromycete Geosiphon (Kluge et al., 2002). Only about 10\% of presently known lichen-forming fungi associate with cyanobacteria. The others establish their symbioses with green algae (Chlorophyta), especially with trebouxiophytes (Škaloud and Peksa, 2010; Ruprecht et al., 2012; Muggia et al., 2013; Dal Grande et al., 2014; Sadowska-Deś et al., 2014) and species of Trentepohliales (López-Bautista, 2006; Rindi et al., 2009), or more rarely with other types of eukaryotic algae (Thüs et al., 2011). 
At present, lichen-symbiotic cyanobacteria cannot usually be identified to clearly delimited species. This is partly due to fundamental problems in the species level taxonomy of cyanobacteria. From early 19th century to the late 20th century, many genera and species of "blue-green algae" were described on the basis of morphology and life-history traits (e.g., Geitler, 1932). While cyanobacteria are now known to belong to Eubacteria, cyanobacterial taxa can still be described following two sets of rules, i.e., those of the Botanical and the Bacteriological Code of Nomenclature, respectively (Oren, 2004, 2011; Oren and Tindall, 2005; Komárek, 2006, 2010a, 2011). At the genus level the standardized molecular method currently used for identifying cyanobacteria is 16S rRNA gene sequencing. While many traditional Geitlerian genera are confirmed, the species cannot usually be delimited on the basis of 16S rRNA sequences alone (Komárek, 2010b). An additional problem is that the phenotypic and genotypic features of many symbiotic cyanobacteria are drastically modified in symbiosis (e.g., Ran et al., 2010).

While the species level taxonomy of symbiotic cyanobacteria remains a challenge, DNA methods now offer a practical way for accurately identifying cyanobacterial genotypes from both fresh lichen specimens (Rikkinen, 2013) and old herbarium material (Palinska et al., 2006). As yet, the genotypic identity of the cyanobiont has only been determined from a minute fraction of all cyanolichen species. This refers not only to the cyanobionts of rare, inconspicuous, or cryptic taxa, but also to those of many common and widely distributed species.

Nostoc is by far the most commonly encountered genus of cyanobacteria in lichen symbioses (Rikkinen, 2013). Many Nostoc genotypes are symbiotic, either serving as a source of fixed carbon and nitrogen, as in cyanolichens (Figs. $4 a$ and $4 b$ ), or solely as a source of nitrogen, as in plant symbioses. Also other nostocalean and stigonematalean genera, like the recently circumscribed Rhizonema (Lücking et al., 2009, 2013; Dal-Forno, 2013), are known to include lichen cyanobionts (Figs. 4c and 4d). For example, Calothrix, Dichothrix, and Stigonema are thought to include lichensymbiotic forms (e.g., Tschermak-Woess, 1988, Voytsekhovich et al., 2011a, 2011b), but their occurrences remain to be confirmed by molecular methods (Komárek, 2010b). Lichenomycetes are believed to associate with Gleocapsa, Anacystis, and other genera distantly related to nostocalean and stigonematalean cyanobacteria (Tschermak-Woess, 1988; Voytsekhovich et al., 2011a, 2011b). Also their identities remain to be confirmed and studied with molecular methods.

Many recent studies have firmly established that lichen-symbiontic Nostoc genotypes are closely related to plant symbiotic and free-living forms of the same genus (Rikkinen, 2013). They have shown that the mycobionts of cyanolichens tend to be highly selective with respect to their 
cyanobionts (e.g., O’Brien et al., 2013; Miadlikowska, 2014b; Magain and Sérusiaux, 2014). In most cases only one or a few closely related cyanobacterial genotypes serve as the appropriate symbiotic partner for individual fungal taxa, while all bipartite cyanolichen species so far analyzed have had only one cyanobiont genotype within each thallus, some of them can house different cyanobionts in different thalli. Furthermore, some cyanobacterial genotypes are shared by several unrelated fungal species. This shared specificity may give rise to facilitative interactions between different cyanolichens. For example, the establishment of an ascospore-dispersed cyanolichen may be effectively facilitated by the prior establishment of another species that distributes the shared cyanobiont within its symbiotic propagules. In any case, the unequal availability of appropriate cyanobionts is likely to explain many interesting patterns of cyanolichen species occurrence (Rikkinen, 1995, 2003, 2013).

\section{Ecological Perspectives}

Cyanolichens occur in many types of terrestrial environments ranging from Arctic tundra and semideserts to tropical rainforests. Whereas green algal lichens can achieve positive net gas exchange when exposed to high atmospheric humidity alone, a corresponding effect in cyanolichens requires direct exposure to liquid water. Their diversity tends to be highest in humid and relatively cool climates characteristic of many tropical mountains (Fig. 5a) and maritime regions of higher latitudes (Fig. 5b). In the temperate zone, many epiphytic species are restricted to old growth forests and have been adversely affected by logging as well as acid precipitation and human-induced changes in air quality. Under favorable conditions, cyanolichens contribute significantly to epiphyte biomass and the nitrogen cycle of the ecosystem (e.g., Elbert et al., 2012). Recently, Hodkinson et al. (2014) demonstrated the presence and transcription of genes encoding enzymes for two different nitrogen fixation pathways (molybdenum- and vanadium dependent systems) in lichen-associated Nostoc. Such flexibility may be very significant for lichens, which often grow on nutrient-poor substrates and get most of their mineral nutrition through aerial deposition (Fig. 5e). Some cyanolichens are important components of biological soil crusts in savannas, semi-deserts, deserts, and disturbed sites, where they help to stabilize the soil and contribute to its fertility (Pietrasiak et al., 2013; Büdel et al., 2014). In some regions their diversity is seriously threatened by overgrazing and climate change. 
One emerging theme in cyanolichens is the possible role of toxic cyanobacterial metabolites in the ecology of cyanolichens. Recent studies have demonstrated that some lichen-symbiotic cyanobacteria produce significant amounts of microcystin and other toxic peptides in situ (Oksanen et al., 2004; Kaasalainen et al., 2009, 2012, 2013). Microcystins are more familiar from cyanobacterial blooms in aquatic ecosystems, where they have caused animal poisonings around the world. In terrestrial ecosystems, cyanolichens represent a potential source of hepatotoxins for grazers. Many molluscs and arthropods, but also mammals feed on lichens (Fig. 5d) and mollusc grazing has been identified as the limiting ecological factor for cyanolichens in some humid forest ecosystems (e.g., Gauslaa, 2008). Many lichen-forming fungi produce toxic secondary substances as a defense against herbivores. It is possible that the cyanobionts of some lichens contribute to the defense by producing toxic compounds.

Kaasalainen et al. (2012) proposed that the high diversity of microcystin variants and related genes in lichen-symbiotic cyanobacteria could partly reflect the effects of their lichen-symbiotic way of life and dispersal. When packaged into propagules of symbiotically dispersing lichens, the population size of the cyanobionts is reduced and they invariably experience a severe genetic bottleneck. At the same time, the close symbiotic association with the fungal partner can promote the evolution of different traits from those commonly seen in free-living cyanobacteria (e.g., Ran et al., 2010). The recurrent bottlenecks and other population-shaping-effects may have been important in generating the genetic and chemical diversity, now seen in the cyanobacterial symbionts of lichens.

\section{Conclusions}

We are still only beginning to understand the complex network of biological interactions and evolutionary processes in which symbiotic cyanobacteria and their fungal partners evolve. Many recent findings indicate that we have been crudely underestimating the biological diversity hidden within cyanolichens and other lichen symbioses. DNA techniques offer practical methods for studying the genetic diversity of symbiotic cyanobacteria in situ, and for making accurate comparisons between lichen cyanobionts and their non-symbiotic relatives. In the future, we can expect many intriguing new results concerning the cyanobionts of previously ignored lichen lineages and unexplored ecological settings. They can significantly improve our understanding of the biology lichens and of symbiosis as a whole. 


\section{References}

Aptroot A, Schumm F (2009) Chimeras occur on the pantropical Lichinomycete Phyllopeltula corticola. Lichenologist 42: 307-310.

Bates ST, Cropsey GWG, Caporaso JG, Knight R, Fierer N (2011) Bacterial communities associated with the lichen symbiosis. Appl Environ Microbiol 77: 1309-1314.

Brodo IM, Richardson DHS (1979) Chimeroid associations in the genus Peltigera. Lichenologist 10: 157-170.

Büdel B, Colesie C, Green TGA, Grube M, Suau RL, Loewen-Schneider K, Maier S, Peer T, Pintado A, Raggio J, Ruprecht U, Sancho LG, Schroeter B, Türk R, Weber B, Wedin M, Westberg M, Williams L, Zheng L (2014) Improved appreciation of the functioning and importance of biological soil crusts in Europe: The Soil Crust International Project (SCIN). Biodiv Cons 23: 1639-1658.

Chua JP, Wallace EJ, Yardley JA, Duncan EJ, Dearden PK, Summerfield TC (2012) Gene expression indicates a zone of heterocyst differentiation within the thallus of the cyanolichen Pseudocyphellaria crocata. New Phytol 196: 862-872.

Dal-Forno M, Lawrey JD, Sikaroodi M, Bhattarai S, Gillevet PM, Sulzbacher M, Lücking R (2013) Starting from scratch: Evolution of the lichen thallus in the basidiolichen Dictyonema (Agaricales: Hygrophoraceae). Fun Bio 117: 584-598.

Dal Grande F, Beck A, Cornejo C, Singh G, Cheenacharoen S, Nelsen MP, Scheidegger C (2014) Molecular phylogeny and symbiotic selectivity of the green algal genus Dictyochloropsis s.I. (Trebouxiophyceae): A polyphyletic and widespread group forming photobiont-mediated guilds in the lichen family Lobariaceae. New Phytol 202: 455-470.

Deusch O, Landan G, Roettger M, Gruenheit N, Kowallik KV, Allen JF, Martin W, Dagan T (2008) Genes of cyanobacterial origin in plant nuclear genomes point to a heterocyst-forming plastid ancestor. $\mathrm{Mol}$ Biol Evol 25: 748-761.

Di Rienzi SC, Sharon I, Wrighton KC, Koren O, Hug LA, Thomas BC, Goodrich JK, Bell JT, Spector TD, Banfield JF, Ley RE (2014) The human gut and groundwater harbor non-photosynthetic bacteria belonging to a new candidate phylum sibling to Cyanobacteria. eLife 2013; 2: e01102.

Elbert W, Weber B, Burrows S, Steinkamp J, Büdel B, Andreae MO, Pöschl U (2012) Contribution of cryptogamic covers to the global cycles of carbon and nitrogen. Nat Geosci 5: 459-462.

Gauslaa Y (2008) Mollusc grazing may constrain the ecological niche of the old forest lichen Pseudocyphellaria crocata. Plant Biol 10: 711-717.

Geitler L (1932) Cyanophyceae. In: L. Rabenhorst (ed). Kryptogamen-Flora. 14. Band. Akademische Verlagsgesellschaft, Leipzig, p. 1196.

Goffinet B, Bayer RJ (1997) Characterization of mycobionts of phytomorph pairs in the Peltigerineae (lichenized ascomycetes) based on internal transcribed spacer sequences of the nuclear ribosomal DNA. Fun Gen Biol 21: 228-237.

Grube M, Cardinale M, de Castro JV, Müller H, Berg G (2009) Species-specific structural and functional diversity of bacterial communities in lichen symbioses. ISME J 3: 1105-1115.

Heiðmarsson S, Mattsson J-E, Moberg R, Nordin A, Santesson R, Tibell L (1997) Classification of lichen photomorphs. Taxon 46: 519-520.

Henskens FL, Green TG, Wilkins A (2012) Cyanolichens can have both cyanobacteria and green algae in a common layer as major contributors to photosynthesis. Ann Bot 110: 555-563.

Hodkinson BP, Allen JL, Forrest L, Goffinet B, Sérusiaux E, Andrésson ÓS, Miao V, Bellenger JP, Lutzoni F (2014) Lichen-symbiotic cyanobacteria associated with Peltigera have an alternative vanadium-dependent nitrogen fixation system. Eur J Phycol 49: 11-19. 
Hodkinson BP, Lutzoni F (2009) A microbiotic survey of lichen-associated bacteria reveals a new lineage from the Rhizobiales. Symbiosis 49: 163-180.

Hodkinson BP, Gottel NR, Schadt CW, Lutzoni F (2012) Photoautotrophic symbiont and geography are major factors affecting highly structured and diverse bacterial communities in the lichen microbiome. Environ Microbiol 14: 147-161.

James PW, Henssen A (1976) The morphological and taxonomic significance of cephalodia. In: Brown DH, Hawksworth DL, Bailey RH (eds). Lichenology, Progress and Problems. Academic Press, London, pp. 2777.

Junttila S, Laiho A, Gyenesei A, Rudd S (2013) Whole transcriptome characterization of the effects of dehydration and rehydration on Cladonia rangiferina, the grey reindeer lichen. BMC Genomics 14: 870.

Kaasalainen U. Jokela J, Fewer DP, Sivonen K, Rikkinen J (2009) Microcystin production in the tripartite cyanolichen Peltigera leucophlebia. Mol Plant Microbe Inter 22: 695-702.

Kaasalainen U, Fewer DP, Jokela J, Wahlsten M, Sivonen K, Rikkinen J (2012) Cyanobacteria produce a high variety of hepatotoxic peptides in lichen symbiosis. Proc Natl Acad Sci USA 109: 5886-5891.

Kaasalainen U, Fewer DP, Jokela J, Wahlsten M, Sivonen K, Rikkinen J (2013) Lichen species identity and diversity of cyanobacterial toxins in symbiosis. New Phytol 198: 647-651.

Kampa A, Gagunashvili AN, Gulder TA, Morinaka BI, Daolio C, Godejohann M, Miao VP, Piel J, Andrésson Ó (2013) Metagenomic natural product discovery in lichen provides evidence for a family of biosynthetic pathways in diverse symbioses. Proc Natl Acad Sci USA 110: E3129-3137.

Kluge M, Mollenhauer D, Wolf E, Schüßler A (2002) The Nostoc-Geosiphon endocytobiosis, In: Rai AN, Bergman B, Rasmussen U (eds). Cyanobacteria in Symbiosis. Kluwer Publications, Dordrecht, pp. 19-30.

Komárek J (2006) Cyanobacterial taxonomy: Current problems and prospects for the integration of traditional and molecular approaches. Algae 21: 349-375.

Komárek J (2010a) Modern taxonomic revision of planktic nostocacean cyanobacteria: A short review of genera. Hydrobiologia 639: 231-243.

Komárek J (2010b) Recent changes (2008) in cyanobacteria taxonomy based on a combination of molecular background with phenotype and ecological consequences (genus and species concept). Hydrobiologia 639: 245-259.

Komárek J (2011) Introduction to the 18th IAC Symposium in České Budějovice 2010, Czech Republic —some current problems of modern cyanobacterial taxonomy. Fottea 11: 1-7.

Lawrey JD, Diederich P (2011) Lichenicolous fungi - worldwide checklist, including isolated cultures and sequences available. In: http:// www.lichenicolous.net [1/27/2012]. Accessed 29 July 2014.

López-Bautista JM, Rindi F, Guiry MD (2006) Molecular systematics of the subaerial green algal order Trentepohliales: An assessment based on morphological and molecular data. Int J Syst Evol Microbiol 56: 1709-1715.

Lücking R, Lawrey JD, Sikaroodi M, Gillevet PM, Chaves JL, Sipman HJM, Bungartz F (2009) Do lichens domesticate photobionts like farmers domesticate crops? Evidence from a previously unrecognized lineage of filamentous cyanobacteria. Am J Bot 96: 1409-1418.

Lücking R, Barrie FR, Genney D (2013) Dictyonema coppinsii, a new name for the European species known as Dictyonema interruptum (Basidiomycota: Agaricales: Hygrophoraceae), with a validation of its photobiont Rhizonema (Cyanoprokaryota: Nostocales: Rhizonemataceae). Lichenologist 46: 261-267.

Lücking R. Dal-Forno M, Sikaroodi M, Gillevet PM, Bungartz F, Moncada D, Yánez-Ayabaca A, Chaves JL, Coca LF, Lawrey JD (2014) A single macrolichen constitutes hundreds of unrecognized species. Proc Natl Acad Sci USA 111: 11091-11096. 
Lumbsch TH, et al. (2011) One hundred new species of lichenized fungi: A signature of undiscovered global diversity. Phytotaxa 18: 1-127.

Magain N, Goffinet B, Sérusiaux E (2012) Further photomorphs in the lichen family Lobariaceae from Reunion (Mascarene archipelago) with notes on the phylogeny of Dendriscocaulon cyanomorphs. Bryologist 115: 243-254.

Magain N, Sérusiaux E (2014) Do photobiont switch and cephalodia emancipation act as evolutionary drivers in the lichen symbiosis? A case study in the Pannariaceae (Peltigerales). PLoS One 9: e89876.

Miadlikowska J, Kauff F, Högnabba F, et al. (2014) Multigene phylogenetic synthesis for the class Lecanoromycetes (Ascomycota): 1307 fungi representing 1139 infrageneric taxa, 312 genera and 66 families. Mol Phyl Evol 79: 132-168.

Miadlikowska J, Richardson DHS, Magain N, Ball B, Anderson F, Cameron R, Lendemer J, Truong C, Lutzoni F (2014b) Phylogenetic placement, species delimitation, and cyanobiont identity of endangered aquatic Peltigera species (lichen-forming Ascomycota, Lecanoromycetes). Am J Bot 101: 1141-1156.

Moncada B, Coca LF, Lücking R (2013) Neotropical members of Sticta (lichenized Ascomycota: Lobariaceae) forming photosymbiodemes, with the description of seven new species. Bryologist 116: 169-200.

Moncada B, Lücking R, Suárez A (2014a) Molecular phylogeny of the genus Sticta (lichenized Ascomycota: Lobariaceae) in Colombia. Fun Div 64: 205-231.

Moncada B, Ready B, Lücking R (2014b) A phylogenetic revision of Hawaiian Pseudocyphellaria sensu lato (lichenized Ascomycota: Lobariaceae) reveals eight new species and a high degree of inferred endemism. Bryologist 11: 119-160.

Muggia L, Nelson P, Wheeler T, Yakovchenko LS, Tonsberg T, Spribille T, (2011) Convergent evolution in a symbiotic duet: The case of the lichen genus Polychidium (Peltigerales, Ascomycota). Am J Bot 98: 16471656.

Muggia L, Vancurova L, Škaloud P, Peksa O, Wedin M, Grube M (2013) The symbiotic playground of lichen thalli - a highly flexible photobiont association in rock-inhabiting lichens. FEMS Microbiol Ecol 85: 313323.

Nash TH III (2008) Nitrogen, its metabolism and potential contribution to ecosystems. In: Nash TH III (ed). Lichen Biology. 2nd edn. Cambridge University Press, Cambridge, pp. 216-233.

O'Brien HE, Miadlikowska J, Lutzoni F (2013) Assessing population structure and host specialization in lichenized cyanobacteria. New Phytol 198: 557-566.

Oksanen I, Jokela J, Fewer DP, Wahlsten M, Rikkinen J, Sivonen K (2004) Discovery of rare and highly toxic microcystins from lichen associated cyanobacterium Nostoc sp. strain 10-102-I. Appl Env Microb 70: $5756-5763$.

Oren A (2004) A proposal for further integration of the cyanobacteria under the Bacteriological Code. Int J Syst Evol Microbiol 54: 1895-1902.

Oren A (2011) Naming Cyanophyta/Cyanobacteria - a bacteriologist's view. Fottea 11: 9-16.

Oren A, Tindall BJ (2005) Nomenclature of the cyanophyta/cyanobacteria/cyanoprokaryotes under the International Code of Nomenclature of Prokaryotes. Algol Stud 117: 39-52.

Palinska KA, Thomasius CF, Marquardt J, Golubic S (2006) Phylogenetic evaluation of cyanobacteria preserved as historic herbarium exsiccata. Int J Syst Evol Microbiol 56: 2253-2263.

Paulsrud P, Rikkinen J, Lindblad P (1998) Cyanobiont specificity in some Nostoc-containing lichens and a Peltigera aphthosa photosymbiodeme. New Phytol 139: 517-524.

Pietrasiak N, Regus JU, Johansen JR, Lam D, Sachs JL, Santiago LS (2013) Biological soil crust community types differ in key ecological functions. Soil Biol Biochem 65: 168-171.

Poelt J, Mayhofer H (1988) Über Cyanotrophie bei Flechten, Plant Syst Evol 158: 265-281. 
Rambold G, Triebel D (1992) The inter-lecanoralean associations. Bibl Lichenol 48: 1-201.

Ran L, Larsson J, Vigil-Stenman T, Nylander JA, Ininbergs K, Zheng WW, Lapidus A, Lowry S, Haselkorn R, Bergman B (2010) Genome erosion in nitrogen-fixing vertically transmitted endosymbiotic multicellular cyanobacterium. PLoS One 5: e11486.

Rikkinen J (1995) What's behind the pretty colours? A study on the photobiology of lichens. Bryobrothera 4: 1-239.

Rikkinen J (2002) Cyanolichens: An evolutionary overview. In: Rai AN, Bergman B, Rasmussen U (eds). Cyanobacteria in Symbiosis. Kluwer Publications, Dordrecht, pp. 73-96.

Rikkinen J (2003) Ecological and evolutionary role of photobiont-mediated guilds in lichens. Symbiosis 34: 99-110.

Rikkinen J (2013) Molecular studies on cyanobacterial diversity in lichen symbioses. MycoKeys 6: 3-32.

Rindi F, Lam DW, López-Bautista JM (2009) Phylogenetic relationships and species circumscription in Trentepohlia and Printzina (Trentepohliales, Chlorophyta). Mol Phyl Evol 52: 329-339.

Rousk K, Jones DL, Deluca TH (2013) Moss-cyanobacteria associations as biogenic sources of nitrogen in boreal forest ecosystems. Front Microbiol 4: 150.

Ruprecht U, Brunauer G, Printzen C (2012) Genetic diversity of photobionts in Antarctic lecideoid lichens from an ecological view point. Lichenologist 44: 661-678.

Sadowska-Deś AD, Dal Grande F, Lumbsch HT, Beck A, Otte J, Hur JS, Kim JA, Schmitt I (2014) Integrating coalescent and phylogenetic approaches to delimit species in the lichen photobiont Trebouxia. Mol Phylog Evol 76: 202-210.

Schirrmeister BE, Antonelli A, Bagheri HC (2011) The origin of multicellularity in cyanobacteria. BMC Evol Biol 11: 45.

Schirrmeister BE, de Vos JM, Antonelli A, Bagheri HC (2012) Evolution of multicellularity coincided with increased diversification of cyanobacteria and the Great Oxidation Event. Proc Natl Acad Sci USA 110: 1791-1796.

Schultz M, Arendholz WR, Büdel B (2001) Origin and evolution of the lichenized ascomycete order Lichinales: Monophyly and systematic relationships inferred from ascus, fruiting body and SSU rDNA evolution. Plant Biol 3: 116-123.

Sigurbjörnsdóttir MA, Heiðmarsson S, Jónsdóttir AR, Vilhelmsson O (2014) Novel bacteria associated with Arctic seashore lichens have potential roles in nutrient scavenging. Can J Microbiol 60: 307-317.

Shih PM, Matzke NJ (2013) Primary endosymbiosis events date to the later Proterozoic with cross-calibrated phylogenetic dating of duplicated ATPase proteins. Proc Natl Acad Sci USA 110: 12355-12360.

Škaloud P, Peksa O (2010) Evolutionary inferences based on nrITS rDNA and actin sequences reveal extensive diversity of the common lichen alga Asterochloris (Trebouxiophyceae, Chlorophyta). Mol Phyl Evol 54: 36-46.

Stenroos S, Stocker-Wörgötter E, Yoshimura I, Myllys L, Thell A, Hyvönen J (2003) Culture experiments and DNA sequence data confirm the identity of Lobaria photomorphs. Can J Bot 81: 232-247.

Thüs H, Muggia L, Pérez-Ortega S, Favero-Longo SE, Joneson S, O’Brien H, Nelsen MP, Duque-Thüs R, Grube M, Friedl T, Brodie J, Andrew CJ, Lücking R, Lutzoni F, Gueidan C (2011) Revisiting photobiont diversity in the lichen family Verrucariaceae (Ascomycota). Eur J Phycol 46: 399-415.

Tønsberg T, Holtan-Hartwig J (1983) Phycotype pairs in Nephroma, Peltigera and Lobaria in Norway. Nordic J Bot 3: 681-688.

Tschermak-Woess E (1988) The algal partner, In: Galun M (ed). CRC Handbook of Lichenology, Vol. I. CRC Press, Boca Raton, pp. 39-92. 
U'Ren JM, Lutzoni F, Miadlikowska J, Laetsch AD, Arnold AE (2012) Host- and geographic structure of endophytic and endolichenic fungi at a continental scale. Am J Bot 99: 898-914.

Voytsekhovich A, Mikhailyuk TI, Darienko TM (2011a). Lichen photobionts. 1: Biodiversity, ecophysiology and co-evolution with the mycobiont. Algologia 21: 3-26.

Voytsekhovich A, Mikhailyuk TI, Darienko TM (2011b) Lichen photobionts. 2: Origin and correlation with mycobiont. Algologia 21: 151-177.

Wang YY, Liu B, Zhang XY, Zhou QM, Zhang T, Li H, Yu YF, Zhang XL, Hao XY, Wang M, Wang L, Wei JC (2014) Genome characteristics reveal the impact of lichenization on lichen-forming fungus Endocarpon pusillum Hedwig (Verrucariales, Ascomycota). BMC Genomics 15: 34.

Werth S, Millanes AM, Wedin M, Scheidegger C (2013) Lichenicolous fungi show population subdivision by host species but do not share population history with their hosts. Fung Biol 117: 71-84.

Zehr JP (2011) Nitrogen fixation by marine cyanobacteria. Trends Microbiol 19: 162-173. 

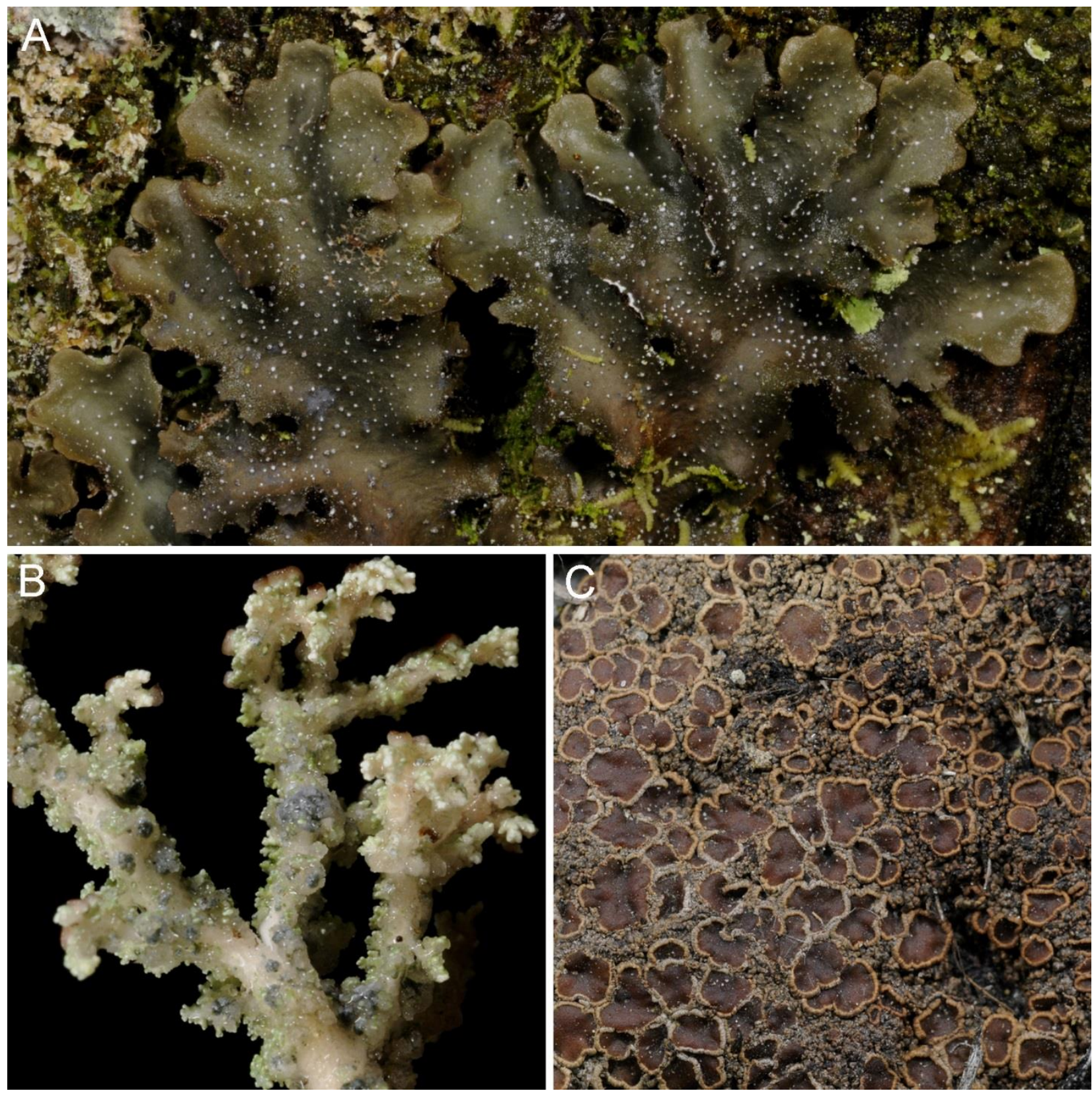

Figure 1. Cyanolichen growth forms. (a) Foliose bipartite cyanolichen (Pseudocyphellaria sp., Peltigerales). The cyanobacterial symbiont (Nostoc) forms a continuous layer just below the upper cortex of the lichen thallus. (b) Fruticose tripartite cyanolichen (Stereocaulon sp., Lecanorales). The cyanobacterial symbiont (Rhizonema) is housed in wart-like cephalodia, while the green algal symbiont forms the photobiont layer. (c) Crustose bipartite cyanolichen (Psoroma hypnorum, Peltigerales). The cyanobacterial symbiont (Nostoc) forms a continuous layer just below the upper cortex of the lichen thallus. The brown disks are fungal apothecia (fruiting-bodies). 

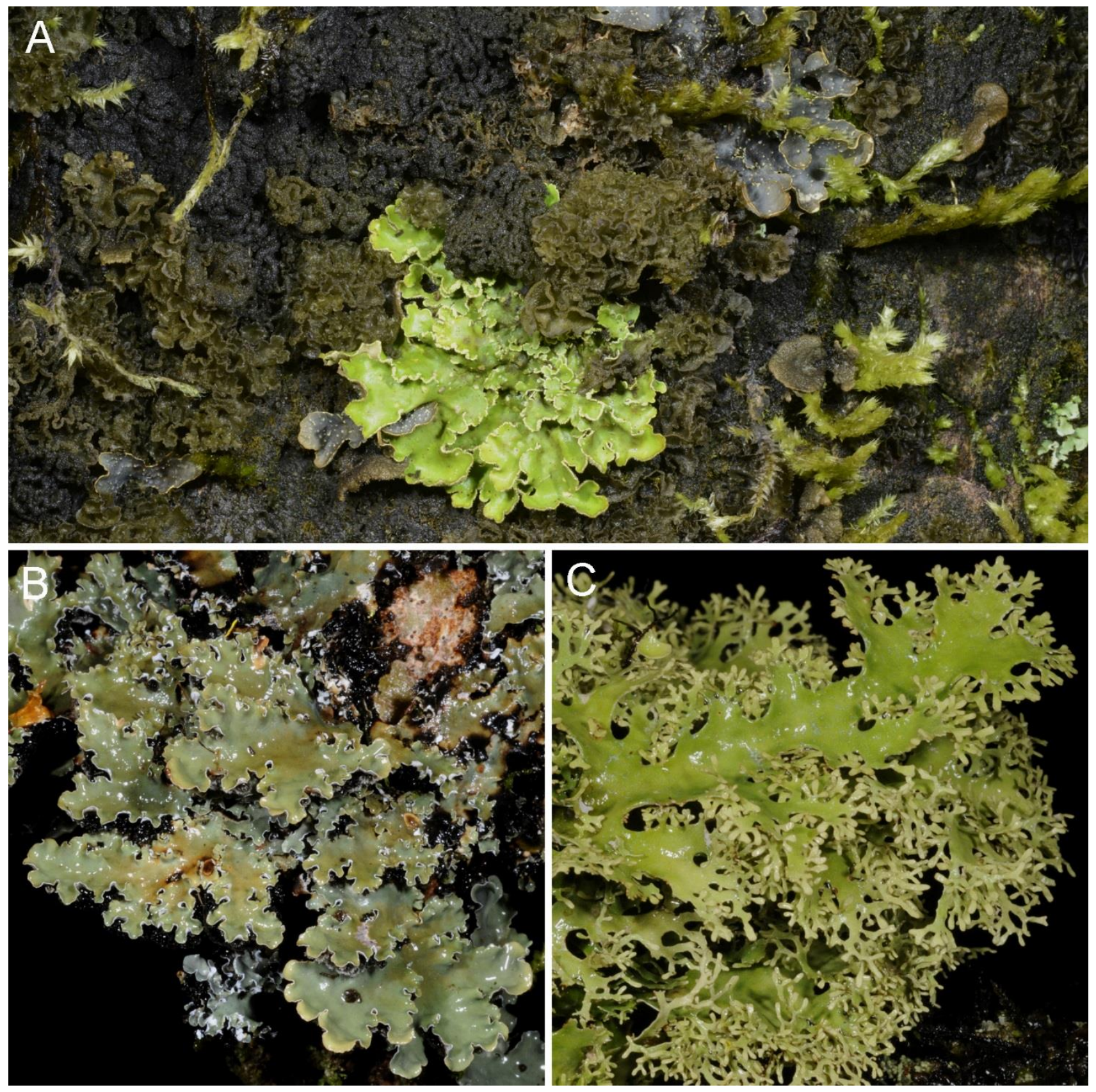

Figure 2. Bipartite and tripartite cyanolichens. (a) A diversity of bipartite and tripartite cyanolichens on tree trunk in tropical moist montane forest. (b) Bipartite cyanolichen (Peltigera sp., Peltigerales) with cyanobacterial symbionts (Nostoc) in a layer just below the upper cortex of the stratified thallus. (c) Tripartite cyanolichen (Pseudocyphellaria sp., Peltigerales) with cyanobacterial symbionts (Nostoc) in cephalodia hidden inside the green algal thallus. 

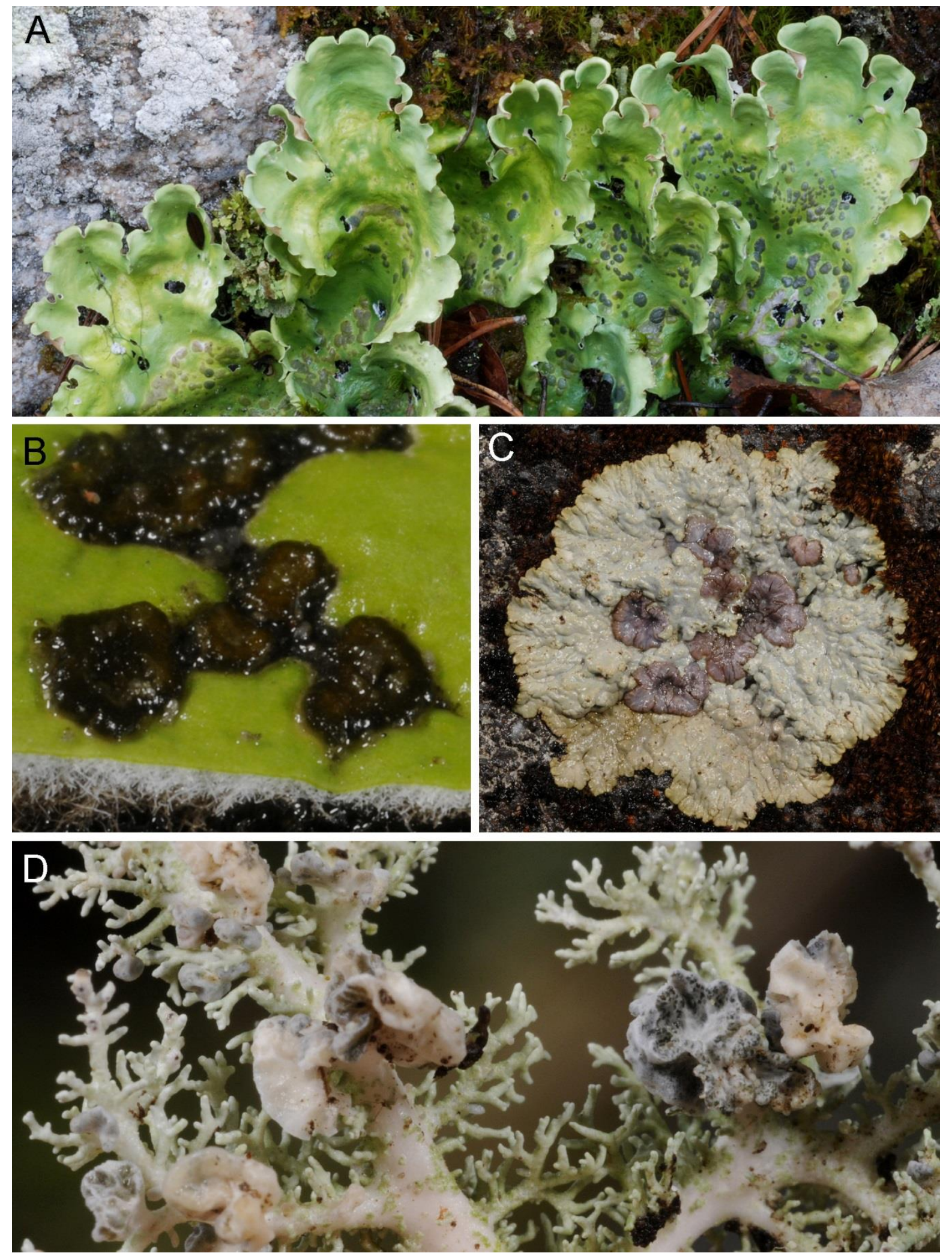

Figure 3. Cephalodia of tripartite cyanolichens. (a) Cephalodia with Nostoc on the upper surface of Nephroma arcticum (Peltigerales). The internal cephalodia are clearly visible through the upper cortex of the hydrated thallus. (b) Small external cephalodia with Nostoc on the upper surface of Peltigera aphthosa (Peltigerales). (c) Large external cephalodia with Nostoc on the upper surface of Placopsis species (Trapeliales). (d) Large sack-like cephalodia with Rhizonema on the main branches of Stereocaulon ramulosum (Lecanorales). 

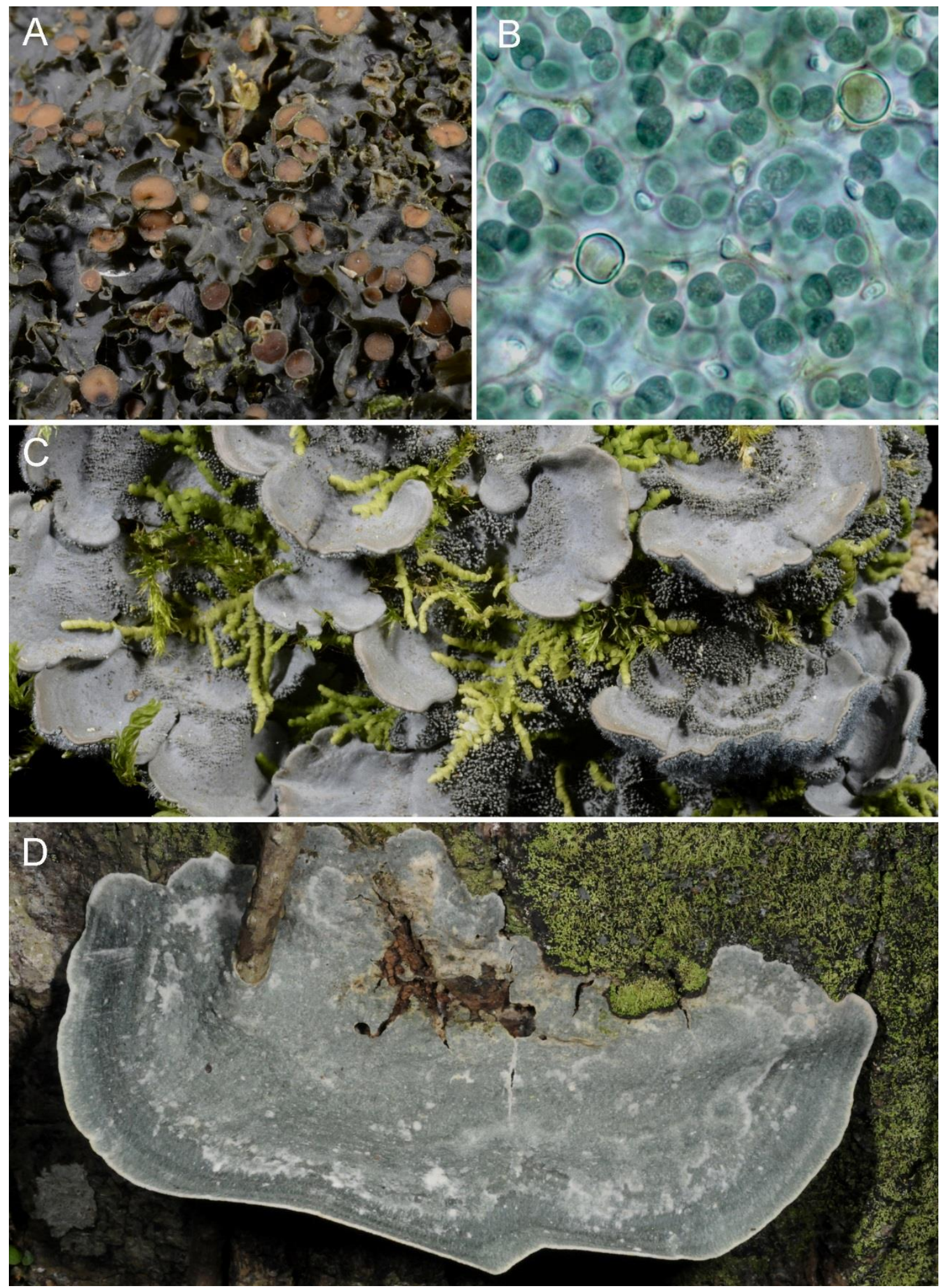

Figure 4. Cyanobacterial diversity in cyanolichens. (a) Gelatinous cyanolichen (Leptogium sp.) with symbiotic cyanobacteria (Nostoc) symbionts in non-stratified thallus; the brown disks are apothecia of the fungal symbiont. (b) The Nostoc cyanobionts of the same lichen photographed through the thin upper cortex of the hydrated thallus. The large clear cells are nitrogen-fixing heterocysts and the small translucent structures are fungal hyphae in optical cross-section. (c) Epiphytic species of Coccocarpia (Peltigerales, Ascomycota) with Rhizonema cyanobiont. (d) Epiphytic species of Dictyonema (Agaricales, Basidiomycota) with Rhizonema cyanobiont. 

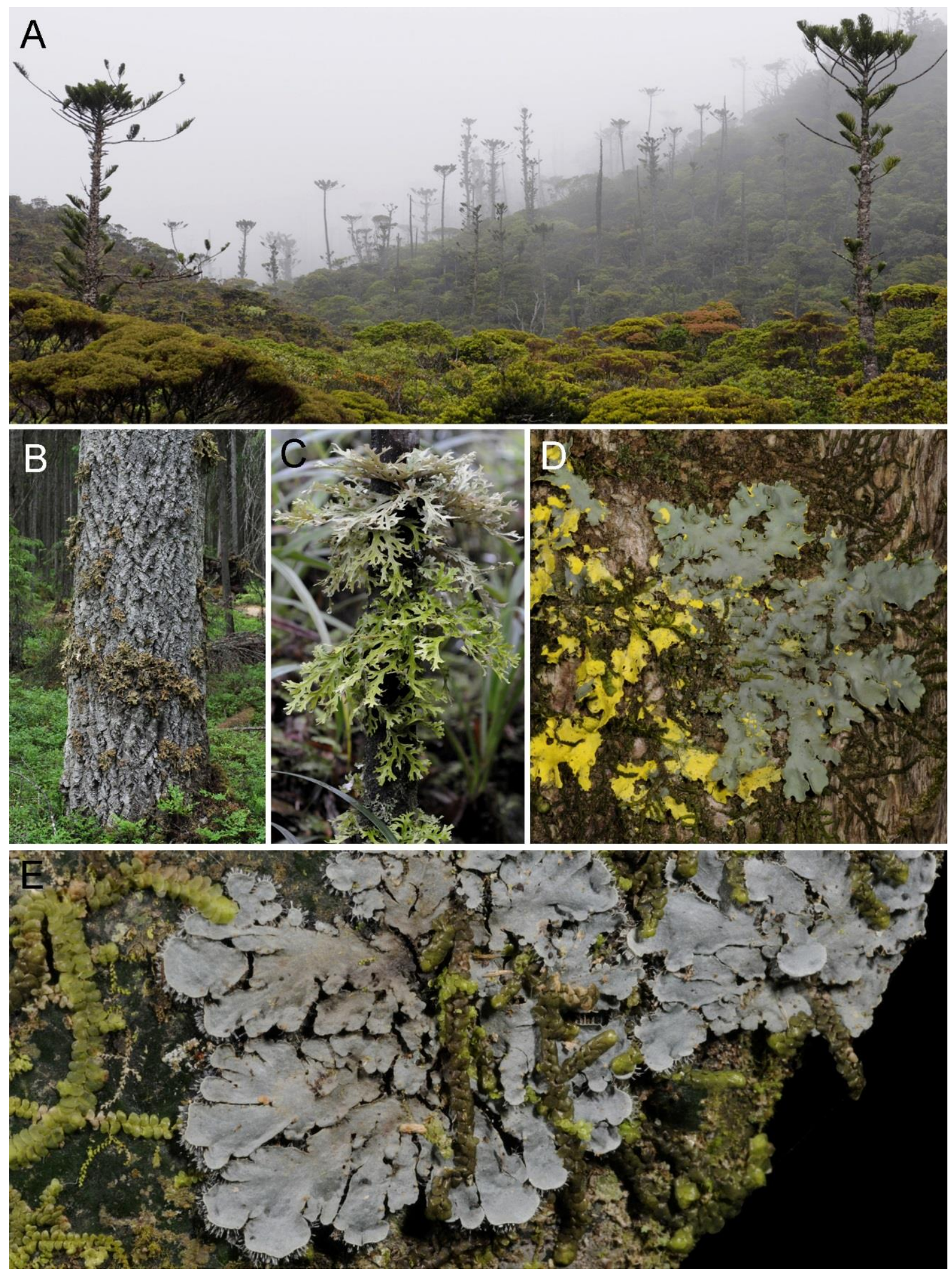

Figure 5. Habitat types rich in cyanolichen species. (a) Tropical moist montane forest on Mont Humboldt in New Caledonia; many cyanolichens (e.g., Peltigera, Pseudocyphellaria, Sticta, and Coccocarpia species) grow as epiphytes and among terricolous bryophytes. (b) Basal trunk of Populus tremula in boreal oldgrowth forest in central Finland; several Peltigera species grow on terricolous bryophytes while epiphytic 
species of other genera (e.g., Lobaria and Nephroma spe-cies) are mainly confined to the basal trunks of deciduous trees. (c) Epiphytic cyanolichens contribute to nitrogen-fixation in many moist forest ecosystems. (d) Molluscs grazing on the upper cortex and photobiont layer of the cyanolichen have revealed the bright yellow medulla of the lichen. The medulla is unpalatable because of accumulation of toxic secondary metabolites produced by the fungus. (e) In tropical rainforests, small Coccocarpia species can grow on angiosperm leaves together with many folicolous liverworts, crustose lichens and fungi. 